\title{
The Role of Chemokines in Cervical Cancers
}

\author{
Fabian Garrido, Carl Mathis Wild, Johanna Mittelberger, Franziska Dobler, Mariella Schneider, Nadine Ansorge, \\ Melitta Köpke, Annamarie Strieder, Nina Ditsch, Udo Jeschke *(i) and Christian Dannecker
}

Citation: Garrido, F.; Wild, C.M.; Mittelberger, J.; Dobler, F.; Schneider, M.; Ansorge, N.; Köpke, M.; Strieder, A.; Ditsch, N.; Jeschke, U.; et al. The Role of Chemokines in Cervical Cancers. Medicina 2021, 57, 1141. https://doi.org/10.3390/ medicina57111141

Academic Editor: Paola Antonini

Received: 9 September 2021

Accepted: 17 October 2021

Published: 21 October 2021

Publisher's Note: MDPI stays neutral with regard to jurisdictional claims in published maps and institutional affiliations.

Copyright: (c) 2021 by the authors. Licensee MDPI, Basel, Switzerland. This article is an open access article distributed under the terms and conditions of the Creative Commons Attribution (CC BY) license (https:/ / creativecommons.org/licenses/by/ $4.0 /)$.
Department of Obstetrics and Gynecology, University Hospital Augsburg, Stenglinstrasse 2, 86156 Augsburg, Germany; fabian.garrido@uk-augsburg.de (F.G.); mathis.wild@uk-augsburg.de (C.M.W.); johanna.mittelberger@uk-augsburg.de (J.M.); Franziska.dobler@uk-augsburg.de (F.D.); Mariella.schneider@uk-augsburg.de (M.S.); nadine.ansorge@uk-augsburg.de (N.A.); melitta.koepke@uk-augsburg.de (M.K.); annamarie.strieder@uk-augsburg.de (A.S.); nina.ditsch@uk-augsburg.de (N.D.); Christian.dannecker@med.uni-augsburg.de (C.D.)

* Correspondence: udo.jeschke@med.uni-augsburg.de; Tel.: +49-821-400-165505

\begin{abstract}
Both clinical-pathological and experimental studies have shown that chemokines play a key role in activating the immune checkpoint modulator in cervical cancer progression and are associated with prognosis in tumor cell proliferation, invasion, angiogenesis, chemoresistance, and immunosuppression. Therefore, a clear understanding of chemokines and immune checkpoint modulators is essential for the treatment of this disease. This review discusses the origins and categories of chemokines and the mechanisms that are responsible for activating immune checkpoints in cervical dysplasia and cancer, chemokines as biomarkers, and therapy development that targets immune checkpoints in cervical cancer research.
\end{abstract}

Keywords: CCL1-28; CXCL1-17; XCL1-2; CX3CL1; immune checkpoints; PD-1; PD-L1

\section{Introduction}

With around 565,000 new cases per year, cervical cancer (CC) is the second most frequent female cancer and the third leading cause for cancer death in female patients worldwide [1,2]. The two main malignant epithelial cervical cancer types are the squamous cell carcinoma and the adenocarcinoma (about $70 \%$ and $10-25 \%$ of all cervix carcinomas, respectively) [3]. A persistent infection with high-risk human papillomavirus (HR-HPV) is the major leading cause of cervical cancer [4]. The tumor micro-environment consists of tumor-infiltrating lymphocytes (TIL) and tumor-associated macrophages (TAM), leading to a Treg and M2 differentiated/polarized immune response [5].

Chemokines, a subgroup of cytokines, are defined as signaling molecules which are responsible for chemotaxis. According to their spacing of the two conserved N-terminal cysteines they are subdivided into four groups: CXC, CC, CX3C, and C.

The $C C$ chemokine proteins (or $\beta$ chemokine proteins) have two adjacent cysteine (amino acids) near their $N$-terminus. At least 27 different members of this subgroup have been described for mammals called CC chemokine ligands (CCL)-1 to -28; CCL10 is identical to CCL9 [6-11]. Members of the CXC chemokine subfamily, on the other hand, have an intermediate amino acid between the first two cysteine; members of the CC chemokine subfamily have two adjacent cysteine. Normally, and with only a few exceptions, members of CXC chemokines are chemotactic for neutrophils, and CC chemokines are chemotactic for monocytes and a small subset of lymphocytes [12-17]. Chemokine (C-motif) ligands (XCL1 and -2) are small cytokines from the family of C chemokines, also known as lymphotactin. In humans, XCL1 is closely related to XCL2, whose gene localization can also be found on chromosome 1 . Both have many genetic and functional similarities; however, XCL2 has so far only been described in the human system. XCL1, together with its receptor XCR1, is involved in cross-presentation, antigen uptake, and the induction of congenital and adaptive cytotoxic immunity. XCR1 is expressed exclusively in conventional 
dendritic cells. XCL1 is secreted by antigen-specific CD8 + T cells and NK cells along with a number of other chemokines. CX3CL1, also known as fractalkine, triggers its adhesive and migration functions by interacting with the CX3CR1 chemokine receptor. Its gene is located on human chromosome 16 along with CCL17 and CCL22. CX3CL1 plays a role in the recruitment of cytotoxic cells and in the elimination of cells that may undergo malignant transformation [15-23].

\section{Material and Methods}

PubMed was searched for articles concerning chemokines and CCL in cervical cancer as well as immune checkpoint in cervical cancer on the 26 July 2021. A total of 97 publications resulted from that search. Publications that met the inclusion criteria were included.

\section{CC Chemokine Ligands (CCL) in Cervical Cancer Biology}

\subsection{CCL2}

Monocyte chemoattractant protein-1 (MCP-1) is also called CCL2 and is one of the most important chemokines that regulates the migration and infiltration of monocytes or macrophages. Both CCL2 and its receptor CCR2 have already been described several times in various malignant diseases and there are also corresponding citations for cervical cancer. Initial indications that this chemokine plays a central role in intercellular communication by inducing an intracellular signaling pathway that negatively affects viral transcription in HPV-positive but still benign cervical cells come from the zur Hausen group [24].

Ongoing work on this topic has indicated that CCL2 (MCP-1) is an important factor that is involved in the interaction between mononuclear cells and human papillomavirus (HPV) -infected cervical epithelial cells. CCL2 is also involved in the negative feed-back loop between the expression of the HPV oncogenes E6/E7 and the MCP-1 gene [25]. In the following studies, the same group showed that hyperplastic squamous epithelium, in addition to cervical cancer, has high CCL2 expression and an increased number of infiltrating macrophages [26]. The induction of HPV-induced tumors is driven by the activation of the virus-specific oncoproteins E6 and E7. The E6 protein, which is specific for HPV types 16 and 18, interacts with the E3 ubiquitin protein ligase, resulting in ubiquitination and proteolysis of the tumor protein p53. E7 inactivates the retinoblastoma protein $(\mathrm{Rb})$ through phosphorylation, which leads to an increase in the free eukaryotic transcription factor E2F (E2F) in the HPV-infected cell. This leads to an increase in the cyclin-dependent kinase inhibitor p16, which is also used as an immunohistochemical marker for HPV-associated cancer. Unfortunately, p16 in carcinogenesis is increased by the E7 oncoprotein [27]. Therefore, mRNA in situ hybridization of E6/E7 or the direct detection of the E6/E7 proteins by immunohistochemistry are the preferred methods for the detection of HPV-induced cancer formation [27]. Work that was done by our own group showed that significantly increased E6 staining is associated with advanced T-status and an increased International Federation of Gynecology and Obstetrics (FIGO) classification in cervical cancer [28]. E6, p53, and p16 demonstrated significantly different expression levels in squamous epithelial tissue compared with adenocarcinomas. MDM2 and gal-3 showed positively correlated expression levels in cervical cancer. In cases with negative p16 expression, Gal-3 expression was also correlated with a poor prognosis. A negative correlation was found between the expression of a mutated form of p53 and of E6 in cervical cancer [28]. In addition, E6 and E7 suppressed CCL2 expression in the primary epithelial cells that were derived from the female genital tract in vitro. Other chemokines, including IP-10, IL-8, and CCL5, were less affected [29]. Another in vitro study showed that overexpression of CCL2 in cervical cancer ME180 cells using viral vectors did not affect their proliferation. However, when treated with a low dose of cisplatin, tumor formation was apparently reduced in clones transduced with CCL2. The histological examination revealed that a considerable number of macrophages infiltrated the tumor sites of MCP-1-transduced cells, which gave initial indications of an immune checkpoint involvement of this cytokine [30]. Another genomic approach revealed that the loss of heterozygosity ( $\mathrm{LOH})$ at 17q11.2 increased the 
cumulative relapse-free survival and cumulative overall survival of cervical cancer patients that were lacking tumor cell-associated CCL2 mRNA, suggesting that the tumor-associated macrophages support tumor progression [31].

A histopathologic study showed that the expression of CCL2 and CCL19 were inversely associated with the expression of atypical chemokine receptors (ACRs), including CCX-CKR, DARC, and D6, which have been reported to be involved in cancer invasion and metastasis in patients with cervical squamous cell carcinoma [32]. D6 expression and co-expression with ACR were negatively related to tumor size and recurrence. Furthermore, the CCX-CKR expression is a positive indicator for overall survival [32]. D6 expression was an independent predictor of both overall and recurrence-free survival [32]. In addition, a recent co-expression network analysis of the atypical chemokine receptor 1 (ACKR1) showed an ACKR1 was negatively correlated with lymph node metastasis and prognosis in cervical cancer [33].

Pahne-Zeppenfield et al. have shown in recent work that squamous cell cervical cancer cells activate monocytes to produce their own CCL2 for further monocyte recruitment and to reprogram their function during differentiation and maturation into dendritic cells (DCs) [34]. The study data also showed that cervical cancer cells suppressed the induction of the chemokine receptor CCR7 in phenotypically mature DCs and prevented their migration to a chemokine that resides in the lymph nodes, which is necessary for initiating adaptive immune responses [34].

An in vitro study showed that TPCA-1, a substance also known as an inhibitor of NF- $\kappa B$, significantly inhibited the release of CCL-2 from HeLa cells (adenocarcinoma of the cervix). TPCA-1 clearly reversed the promoting effect of IL- $1 \beta$ on the vitality of HeLa cells. IL-1 $\beta$ increased cell migration, proliferation, and invasion of HeLa cells by targeting the NF- $\mathrm{B}$ /CCL-2 pathway. The interaction of IL-1 $\beta, \mathrm{NF}-\kappa \mathrm{B}$, and CCL-2 could be a promising subject of investigation in the treatment and prevention of adenocarcinoma of the cervix [35].

Interestingly, the CCL2 receptor, CCR2, prevented the progression from squamous intraepithelial lesions to invasive cervical carcinoma if carrying the polymorphism CCR264I [36]. Additional work of the same group showed that CCR2-64I polymorphism might contribute to the establishment of high-grade squamous intraepithelial lesions through the disruption of the naturally fragile immune response that is directed towards human papillomavirus infection [37]. Another team showed that the CCR2-64I variant was associated with a decreased risk of cervical cancer; homozygote carriers of the 64I variant had an odds ratio of $0.31(0.12-0.77)$. This association has been demonstrated in both carriers and non-carriers of the HLA DQB1 * 0602 cervical cancer risk allele [38].

\subsection{CCL3, CCL4, CCL5, and CCL8}

The chemokine CCL5, better known as RANTES, also belongs to the family of CC chemokines. It is secreted by $\mathrm{T}$ lymphocytes after activation and by fibroblasts, epithelial cells, and endothelial cells after stimulation with TNF- $\alpha, \mathrm{IL}-1 \beta$, and IFN- $\gamma$. CCL5 is a powerful chemoattractant for monocytes, memory T cells, basophils, and eosinophils. In cervical cancer, the CCL5 content was significantly increased in the primary tumor and also in metastatic lesions (lymph nodes or skin) [39].

CCR5 belongs to the group of $\mathrm{G}$ protein-coupled receptors, which act as chemokine receptors in the CC chemokine family. CCR5 binds several chemokines: CCL3, CCL4, CCL5, and CCL8. Chemokine receptor gene polymorphism CCR5 Delta32 patients showed a significant risk enhancement in stage IB cervical cancer [40].

In connection with CCL8 it has already been shown that ZEB1, induced by hypoxia, promotes the progression of cervical cancer through CCL8-dependent tumor-associated macrophage recruitment [41]. In particular, ZEB1 that was induced by hypoxia activated the expression of CCL8, which in turn led to macrophages being attracted via the CCR2NF- $\mathrm{B}$ signaling pathway [41]. In addition, it was found that, based on the data analysis of 
the Cancer Genome Atlas (TCGA), ZEB1 and CCL8 are independent prognostic factors in cervical cancer patients [41].

\subsection{CCL17 and CCL19}

A newly investigated chemokine is CCL17. In vitro studies on HeLa and SiHa (squamous cell carcinoma) cells showed that hypoxia increased the expression of the CCL17 receptor (CCR4) [8]. Recombinant CCL17 led to a dose-dependent increase in cell proliferation in these cell cultures [8]. The blockade of CCL17 with the help of anti-human CCL17 antibodies ( $\alpha$-CCL17) induced the opposite effect [8]. The proliferation of HeLa and SiHa cells could be induced in vitro with the help of hypoxia; treatment with $\alpha$-CCL17 reversed this effect [8]. The proliferation of HeLa and SiHa cells could be reduced by stimulation with the inhibitor for $c$-Jun $N$-terminal kinase (JNK) or a signal transducer and activator of the transcription 5 signaling pathway (STAT5) [8]. These results show that an increased CCL17 expression in cervical lesions is a significant inducer of the proliferation of squamous cells and adenocarcinoma of the cervix via the JNK and STAT5 pathways [8].

Another member of C-C chemokine receptor type is CCR7. CCR7 is a protein that, in humans, binds the chemokines ligand 19 (CCL19/ELC) and (C-C motif) ligand 21 (CCL21). Studies on this receptor showed that HPV16-E6 reactive T cells are preferred in the CD45RA + CCR7 + T cell subpopulation of tumor infiltrating lymphocytes, peripheral blood lymphocytes, and T cells that are harvested from the draining of lymph nodes (T-LN) in patients with squamous cell carcinoma of the uterine cervix. This, in turn, indicates that successful immune defense against HPV16 + tumor cells is inhibited in those patients. The unique CD45RA + /CCR7 + phenotype of HPV antigen-induced T cells can serve as a specific marker for dysfunctional T cells in HPV16-induced squamous cell cervical cancer [42].

\subsection{CCL20 and CCL22}

CCL20 is a chemokine that acts as a chemotactic factor for lymphocytes and neutrophils, but not monocytes. CCL20 is involved in the recruitment of IL17 positive T helper 17 cells (Th17) and the association of T regulatory cells (Treg) at the foci of inflammation. During cervical carcinogenesis, HPV16 E6/E7 induces downregulation of CCL20. The reduced ability of the immune system to control an HPV infection can be explained by this inhibition of CCL20 [43]. In addition, CCL20 is one of its target genes of MicroRNA 21 (miR-21) [44]. The same group showed that miR-21 is significantly overexpressed in human cervical squamous cancer tissues and cell lines [44]. The measured amount of miR-21 correlates with the tumor differentiation and the nodal status. It is also known that miR-21 regulates the proliferation, apoptosis, and migration of HPV16-positive cervical squamous cells [44].

Th17 cells accumulate within tumor tissues and correlate with the recurrence of cervical cancer patients [11]. Recent in vitro migration assays that were established by Yu et al. showed that CCL20 had effective chemotaxis to circulating Th17 cells. In summary, it can be said that Th17 cells are preferentially recruited into tumor tissue via the CCR6CCL20 signal transduction pathway. This newly described pathway could serve as a new therapeutic target for cervical cancer [11]. Another study showed that stromal fibroblasts induce CCL20 through IL6/C/EBP $\beta$ to support the recruitment of Th17 cells during cervical cancer progression [10]. With the help of this study, a novel molecular mechanism was defined, which explains how cervical neoplastic cells form their local microenvironment. This is done by stimulating fibroblasts to support the infiltration of Th17 cells in a paracrine IL-6/C/EBP $\beta$-dependent manner [10].

The CCL20/CCR6-induced epithelial-mesenchymal transition (EMT) development via both Erk1/2 and Akt signaling pathway in squamous cell cervical cancer leads to progression/metastasis [45]. Astrocyte Elevated Gene-1 (AEG-1) has been described as an important mediator involved in EMT [45]. AEG-1 proteins are highly expressed in squamous cell cervical cancer tissues and closely correlated with FIGO stage and metastasis [45]. The 
chemokine CCL20 could be inhibited via E6 and E7 in lesions of the high-risk HPV type to evade the immune response. This was assumed by a study by Jiang and Xue, that showed that there exists a correlation of E6 and E7 levels in high-risk HPV16 type cervical lesions with CCL20 and Langerhans cells [46].

The chemokine CCL22 is known to recruit Treg into tumor tissue and is also expressed in many human tumors [5]. However, the prognostic role in cervical cancer for CCL22 was not clarified until recently [5]. Within a study of our group, we retrospectively analyzed the clinical significance of the expression of CCL22 and FOXP3 in 230 cervical cancer patients. With the help of a tissue microarray (TMA), immunohistochemical staining analyses of CCL22 and FOXP3 were carried out [5]. The number of infiltrating CCL22 ${ }^{\text {hi }}$ cells were also positively correlated with the number of infiltrating FOXP3+ cells [5]. The CCL22 $2^{\text {hi }}$ group had a lower overall survival (OS) compared to the CCL22 $2^{\text {lo }}$ group [5]. In addition, CCL22 ${ }^{\text {hi }}$ is an independent prognostic factor of shorter OS [5]. In the combination group, CCL22h ${ }^{\text {hi }}$ FOXP3 3 hi, the overall survival was significantly lower than the overall survival in the combination group, $\mathrm{CCL} 22^{\mathrm{lo}} \mathrm{FOXP} 3^{\mathrm{lo}}$, regardless of the FIGO stage and disease subtype [5]. Cox regression analysis showed that for CCL22 ${ }^{\text {hi }}$ FOXP $3{ }^{\text {hi }}$ this combination was an independent indicator of a shorter OS. In the group CCL22 ${ }^{\text {hi }} \mathrm{FOXP} 3{ }^{\mathrm{hi}}$, although PFS was in cervical adenocarcinoma significantly lower than that of the group $\mathrm{CCL} 22^{\mathrm{lo}} \mathrm{FOXP} 3^{\mathrm{lo}}$, CCL22 ${ }^{\text {hi }} \mathrm{FOXP} 3{ }^{\text {hi }}$ was not an independent indicator [5]. CCL22 was mainly expressed in M2-like macrophages in CC and induced by cervical cancer cells. The results of our study show that cervical cancer patients with elevated CCL22 + infiltrating cells need more aggressive treatment [5].

A summary of the C-C chemokines, its receptors and main function in cervical cancer is presented in Table 1. The interaction between C-C chemokines and its receptors is displayed in Figure 1.

Table 1. Summary of the C-C-chemokines, its distribution, and the main function in cervical cancer.

\begin{tabular}{|c|c|c|c|c|}
\hline Chemokine. & Effects of the Chemokine & Effects in Cervical Cancer & Receptor & References \\
\hline $\begin{array}{l}\text { CCL2 } \\
(\mathrm{MCP}-1)\end{array}$ & $\begin{array}{l}\text { Migration, infiltration of } \\
\text { monocytes and macrophages }\end{array}$ & $\begin{array}{l}\text { Crosstalk between mononuclear cells } \\
\text { and HPV-infected epithelia }\end{array}$ & CCR-2 & {$[24,26]$} \\
\hline $\begin{array}{c}\text { CCL5 } \\
\text { (RANTES) }\end{array}$ & $\begin{array}{l}\text { Chemoattractant for } \\
\text { monocytes, memory T-cells, } \\
\text { basophils, eosinophils }\end{array}$ & $\begin{array}{l}\text { Elevated in primary tumor and } \\
\text { metastatic lesions }\end{array}$ & CCR-5 & [39] \\
\hline $\begin{array}{l}\text { CCL8 } \\
(\mathrm{MCP}-2)\end{array}$ & $\begin{array}{l}\text { Recruitment of macrophages } \\
\text { via CCR-2- NFkB-pathway }\end{array}$ & $\begin{array}{l}\text { Independent prognosticator for } \\
\text { cervical cancer progression }\end{array}$ & CCR-2 & [41] \\
\hline $\begin{array}{l}\text { CCL17 } \\
\text { (TARC) }\end{array}$ & $\begin{array}{l}\text { Dose-dependent cell } \\
\text { proliferation }\end{array}$ & $\begin{array}{c}\text { High level regulates proliferation of } \\
\text { cervical cancer cells via } \\
\text { JNK/STAT5 pathways }\end{array}$ & CCR-4 & [8] \\
\hline $\begin{array}{l}\text { CCL19 } \\
(\mathrm{MIP}-3 \beta) \\
\text { CCL21 }\end{array}$ & Proinflammatory & $\begin{array}{l}\text { Dysfunctional T-cells in HPV16 } \\
\text { positive cervical cancer cells }\end{array}$ & CCR-7 & {$[42,47]$} \\
\hline $\begin{array}{l}\text { CCL20 } \\
(\mathrm{MIP}-3 \mathrm{~A})\end{array}$ & $\begin{array}{l}\text { Chemoattractant for } \\
\text { lymphocytes and } \\
\text { neutrophils, recruitment of } \\
\text { Th17 and Treg cells }\end{array}$ & Down-regulation by HPV16 E6/E7 & CCR-6 & [11] \\
\hline CCL22 & Recruitment of Treg cells & Independent predictor for shorter OS & CCR-4 & [5] \\
\hline
\end{tabular}

Abbreviations: HPV—human papilloma virus; NFkB—nuclear factor 'kappa-light-chain-enhancer' of activated B-cells; JNK—c-Jun N-terminal kinases; STAT5-Signal transducer and activator of transcription 5; HPV16-HPV type 16; E6-HPV E6 protein; E7-HPV E7 protein; OS-overall survival rate. 


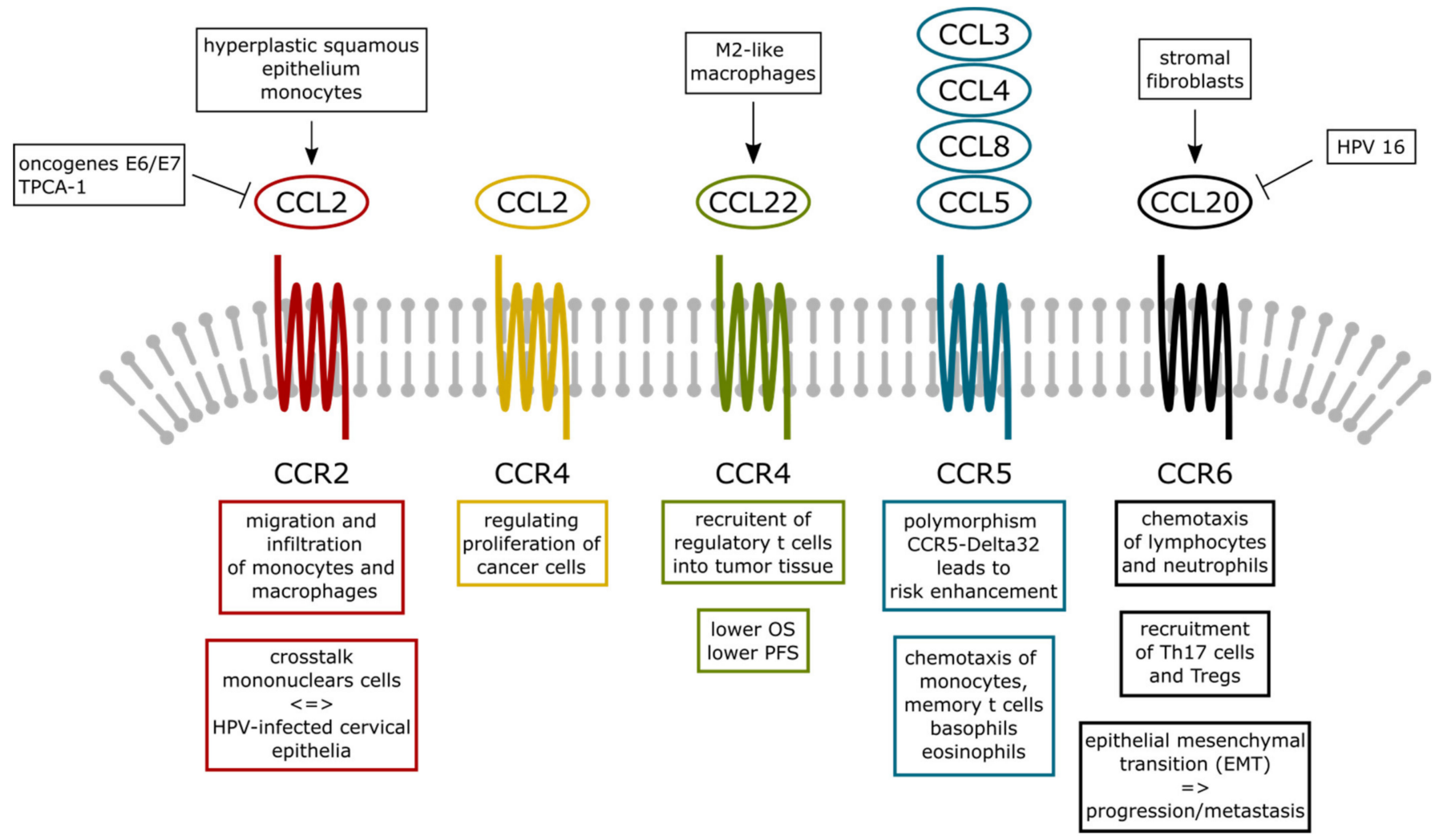

Figure 1. Summary of the described chemokines of the CC chemokine proteins (or $\beta$ chemokine proteins) family. These chemokines have two adjacent cysteine (amino acids) near their amino terminus. Although at least 27 different member of this subgroup have been reported for mammals, referred to as CC chemokine ligands (CCL)- 1 to -28 , we focused in this review on 10 CCL chemokines and described ligand receptor interaction for CCL2, $-3,-4,-5,-8,-20$ and -22 specifically for their function in cervical cancer. Abbreviations: HPV-human papilloma virus; CCL-C-C Motif Chemokine Ligand; C-C chemokine receptor; E6-HPV E6 protein; E7-HPV E7 protein; OS-overall survival rate; TPCA-1-2-[(aminocarbonyl)amino]-5-(4-fluorophenyl)-3-thiophenecarboxamide; Treg-T regulatory cells.

\section{CXC Chemokines and Its Receptors in Cervical Cancer}

\subsection{CXCL1, CXCL2, and CXCL3}

CXCL1 belongs to the family of CXC chemokines, which act as a chemoattractant for several immune cells, particularly neutrophils. It also plays an important role in regulating the immune and inflammatory responses. CXCL1 was previously named GRO1 oncogene, GRO $\alpha$, Neutrophil Activating Protein 3 (NAP-3), and Melanoma Growth Stimulating Activity-Alpha (MGSA- $\alpha$ ) [48]. Interestingly, it is seminal plasma that acts via angiogenic chemokine expression in HeLa cells and thus regulates vascular function specifically via CXCL1 signal transduction [49]. In vitro experiments showed that HeLa cells induced the formation of endothelial cells into a network of tubular structures via the CXCR2 receptor on HUVECs. The data from this study reveal a molecular mechanism by which seminal plasma can modulate the vascular function in HeLa cells with the help of IL-8 and the pro-angiogenic chemokine CXCL1 [49].

A nanomedical study showed that synthesized Annona muricata silver nanoparticles exhibited potent anticancer activities against cervical and prostate adenocarcinomas through the regulation of CASP9 and the CXCL1/CXCR2 gene axis [50].

AKIP1 in cervical cancer cells stimulates the expression of CXCL1, CXCL2, and CXCL8 [51]. By binding to the endothelial receptor CXCR2, these chemokines are involved in endothelial tube formation as well as in the proliferation of cervical cancer cells and in the clone-formation that is induced by the overexpression of AKIP1 [51]. AKIP1-induced chemokine expression was inhibited by a negative inducer of the nuclear factor kappa 
$B$ kinase subunit $\beta$ [51]. Therefore, AKIP1 is critical to the angiogenesis and growth of cervical cancer by increasing levels of the NF- $\mathrm{kB}$-dependent chemokines CXCL1, CXCL2, and CXCL8 [51].

CXCL3 expression was analysed in a combined in vivo and in vitro study and strongly correlated with CXCL5 expression in HeLa cells [52]. In vitro, HeLa cells overexpressing CXCL3 showed enhanced proliferation and migration activities [52]. The overexpression of CXCL3 was also examined in a HeLa cell tumor xenograft model [52]. Mechanistic studies showed that CXCL3 overexpression affected the expression of genes that were associated with the extracellular signal-regulated kinase (ERK) pathway. These studies included ERK1/2, Bcl-2, and Bax. However, exogenous administration of the ERK1/2 blocker PD98059 weakened the CXCL3-induced proliferation and migration effects [52].

\subsection{CXCL5, CXCL6, CXCL8, and CXCL10}

CXCL5 and its receptor CXCR2 are expressed by HeLa cells and CXCL5 is upregulated in cervical cancer tissues [53]. The expression of CXCL5 correlates positively with age, but not with clinical stages and tumor infiltration [53]. The overexpression of CXCL5 and the exogenous administration of CXCL5 contributed to the proliferation and migration activity of Hela cells in vitro. In addition, overexpression of CXCL5 also promoted the growth of HeLa cells in a nude mouse xenograft model [53]. CXCL5 overexpression also regulated the expression of tumor-related genes such as ERK, $p$-ERK, AKT, $p$-AKT, DIABOL, NUMB, NDRG3, and CXCR2 at the gene level [53]. In addition, CXCL5 contributes to the tumorigenicity of cervical cancer and is post-transcriptionally regulated by miR-577 [54]. Knockdown of CXCL5 with specific siRNA transfection in Hela and SiHa cells significantly inhibited cell proliferation and migration and induced apoptosis in vitro [54]. The authors also showed that CXCL5 was a direct target of miR-577 [54].

By inhibiting CXCL6, MicroRNA-101-5p inhibits the growth and metastasis of cervical cancer cells [55]. CXCL6 is the target protein of miR-101-5p in cervical cancer and overregulation of miR-101-5p reduced the tumor growth of cervical cancer cell in vivo [55]. Finally, the mRNA level of CXCL6 was negatively associated with the miR-101-5p level in cervical cancer tissue [55].

CXCL8, a newly investigated cytokine is highly expressed in HeLa and Caski (squamous cell carcinoma of the cervix) cell lines compared with normal cervical tissues in microarray datasets (GSE9750 and GSE7803) [56]. In cervical cancer tissues and cell lines, CXCL8 mRNA and protein expression were increased compared to normal cervical tissues and cervical epithelial cell lines [56]. CXCL8 protein expression was significantly correlated with the clinical stage, distant metastasis, histological type, and histological grade [56]. In summary, it can be said that the high expression of CXCL8 is a negative independent prognostic parameter for cervical cancer patients [56]. In addition, miR-302c-3p and miR-520a-3p suppressed the proliferation of cervical carcinoma cells by targeting CXCL8 [57]. The inhibition of CXCL8 in combination with $\mathrm{miR}-302 \mathrm{c}-3 \mathrm{p}$ and/or miR-520a-3p overexpression had proliferation-suppressing and apoptosis-stimulating effects on cervical cancer cells. In contrast, the restoration of CXCL8 weakened the miR-302c-3p and miR-520a-3p-induced anti-proliferative and pro-apoptotic effects [57].

CXCL10, also known as interferon-gamma-induced protein 10 (IP-10) or small-inducible cytokine B10, decreased as the disease progressed. Accordingly, the prognosis of patients with a low CXCL10 expression in cervical cancer was poor. In addition, CXCL10 levels were significantly inversely correlated with vascular endothelial growth factor (VEGF) levels in cervical cancer. CXCL10 could work to suppress VEGF-associated angiogenesis in the future and can be recognized as a prognostic indicator for both squamous cell and adenocarcinoma of the uterine cervix [58]. Additional experimental data showed that CXCL10 can inhibit the growth of cervical carcinoma through modulating the formation of micro-vessels and the expression of HPV oncoproteins E6 and E7. The results of this group 
also provide further evidence of the anti-tumor effects of CXCL10, which may be relevant in further exploration of the potential applications of this molecule in the treatment of cervical cancer [59]. Recently, a group found that CXCL10 enhances radiotherapy effects in HeLa cells through cell cycle redistribution [60]. Flow cytometry showed that the overexpression of CXCL10 in HeLa cells led to a prolonged G1 phase and a shortened S phase $72 \mathrm{~h}$ after transfection. The subsequent Western blot analysis showed that p27 (Kip1) was upregulated in CXCL10-treated HeLa cells and cyclin E was downregulated [60]. Based on these in vitro findings, mouse models of adenocarcinoma of the cervix were created by inoculation with HeLa cells and were treated by combining intravenously administered plasmid-encoding CXCL10 with direct radiation. The results showed a significant increase in tumor growth inhibition, reduced vessel density, decreased cell proliferation, and increased apoptosis in the cervical cancer cells of the combination therapy group. Therefore, CXCL10 gene therapy in combination with radiation therapy could be a novel and effective therapeutic strategy for the treatment of squamous cell cervical cancer [17].

\subsection{CXCL11 and CXCL12}

The chemokine ligands CXCL11 (which also activates CXCR3) and CXCL12 (which also activates CXCR4) bind to the chemokine receptor CXCR7. CXCR7 does not activate the G protein signaling but does activate $\beta$-arrestin [61]. Interestingly, the CXCR7 expression is associated with reduced disease-free and disease-specific survival in cervical cancer patients [62]. A recent study produced similar results, showing that the expression of CXCR7 and EGFR was associated with shorter disease-free survival (DFS) and overall survival (OS) [63]. The multivariate analyses indicated that CXCR7 was independently associated with DFS and OS [63]. The prevalence of recurrences and distant metastases was significantly lower in the group with external pelvic irradiation with brachytherapy than in the group with radical hysterectomy during CXCR7 expression. In addition, the CXCR7 knockdown significantly reduced the proliferation and invasion of squamous cell cervical cancer cells in vitro [63]. Furthermore, CXCL12 is highly expressed in HeLa cell lines [64]. The silencing of CXCR7 or CCX733 treatment as opposed to CXCR4 silencing or AMD3100 treatment suppressed the proliferation, migration, and invasion of HeLa cells that were stimulated by CXCL12 [64]. In a xenograft tumor model, CXCR7 silencing or CCX733 treatment inhibited the volumes and weight of xenograft tumors. In addition, the inhibition of CXCR7 decreased the expression level of MMP2 and MMP9, and in contrast, CXCR7 inhibition increased TIMP-1 and TIMP-2 in vivo [64].

Specific for CXCL12 is the CXCR-4 receptor, an alpha chemokine receptor with strong chemotactic activity for lymphocytes. CXCL12 is the major modulator of trafficking of myeloid cells (precursors, MDSC, and TAMs). A histopathological study showed that CXCR4 expression is significantly higher in older patients than in younger patients. This increased CXCR4 expression has also been demonstrated in patients with squamous cell and adenocarcinoma of the cervix who had a large tumor size, deep stromal invasion, involvement of the lymphatic space, or lymph node metastasis [65]. Although the chemokine receptor CXCR4 has been shown to be expressed by most cancers, it was originally reported that CXCR4 regulates the migration of lymphocytes into the inflammatory tissues [65]. In vitro experiments were carried out to further evaluate the effect of CXCL12 on the proliferation of cervical cancer cells. Hela cells were cultured for $72 \mathrm{~h}$ and exposed to CXCL12 with and without CXCR4 monoclonal antibody (mAb). The authors found that CXCR4 was expressed on SCC cells in all cervical cancer tissues, metastatic lymph node, and Hela cells, but not in normal cervical tissue. CXCL12 is also expressed on immune cells in lymph nodes. CXCL12 induced the directed migration of Hela cells in a concentration-dependent manner; this migration induction could be inhibited by CXCR4 mAb [66]. An additional study showed that CXCR4 expression is associated with pelvic lymph node metastasis in cervical adenocarcinoma and the addition of CXCL12 provoked significant signal transduction events, including chemotaxis and rescue from apoptosis. The effects described were most likely mediated by the 
activation and phosphorylation of the extracellular signal-regulated kinase $1 / 2$ and AKT pathways [67]. Another approach to studying CXCL12 and its receptor CXCR4 took advantage of the fact that CXCR4 is the most commonly expressed chemokine receptor in most cancers and has been linked to tumor spread and poor prognosis. For this reason, several CXCR4 antagonists have already been tested as potential anti-tumor agents. A new approach to the discovery of chemokine receptor antagonists is the use of bacteria, as described by Walenkamp et al. [68]. Bacteria produce chemokine receptor inhibitors to escape clearance by innate immune cells [68]. The superantigen-like 10 produced by staphylococci inhibited CXCL12-induced calcium mobilization and cell migration in HeLa cells [68]. The group Amin et al. found that the invasion of E6/E7-positive cancer cell lines (HeLa and TC-1) in Matrigel is stimulated by CXCL12-CXCR4 interaction and subsequent Rho/ROCK activation [69]. A high proportion of the cells that were expressing membrane-associated CXCR4 were found in pulmonary metastatic foci that were generated by TC- 1 cells. Cell adhesion and invasion can be abolished by the immunological blockade of CXCR4, as in vitro and in vivo models have shown. These findings can help explain the CXCL12/CXCR4-controlled metastasis process in cervical cancer [69]. Inhibition of CXCR4 or Hedgehog (Hh) gene activity during tumor growth under hypoxic conditions reduced the size of the primary tumor and additionally reduced lymphatic metastasis to levels that were below those seen in control mice that were exposed to normoxic conditions [70].

The invasion of HeLa cells that are induced by CXCL12 is determined by the action of matrix metalloproteinase-9 (MMP-9), as Brule et al. showed [71]. The CXCL12-mediated cell invasion could be inhibited by preincubation of HeLa cells with heparin or with anti-heparan sulfate antibodies or with beta-D-xyloside. In addition, the downregulation of Syndecan-4, a heparan sulfate proteoglycan, decreased CXCL12-mediated HeLa cell invasion. Glycosaminoglycans on Syndecan-4 are likely involved in CXCL12-mediated cell chemotaxis [71]. Jaafar et al. investigated the correlation between CXCL12 expression and FoxP3 + cell infiltration in human papillomavirus infection and also in the clinicopathological progression of cervical cancer [72]. FoxP3 and CXCL12 expression correlated significantly in patients with squamous and glandular neoplasia [72]. Another approach that was proposed by Cai et al., took advantage of the fact that SIVmac 239 -Nef downregulates the cell surface expression of CXCR4 in tumor cells and, therefore, proliferation, migration, and angiogenesis are inhibited [73]. In further experiments, a downregulation of the cell surface of CXCR4 in HeLa cells was observed after the Nef transfection. The proliferation as well as the migration of Nef-transfected HeLa cells in vitro was significantly reduced. The in vitro tube formation was also significantly lower after Nef transfection and CXCR4 knockdown with siRNA [73]. Another experimental study showed that oligomannurarate sulfate inhibits CXCL12-mediated proliferation and invasion of HeLa cells in vitro [74].

CXCL12 induces directed cell migration and also spontaneous metastasis, presumably via activated mTOR (a mechanistic target of rapamycin) in a very effective and pertussissensitive manner. Further experiments showed that the inhibition of the mTOR complex 1 (mTORC1) by rapamycin and mTORC $1 /$ mTORC 2 by Torin 2 reduced the directed cell migration in the direction of CXCL12. The same effects could also be observed through knock-down key components of mTORC1/2, Raptor, and Rictor [75]. Based on that finding, mTORC1 could be a suitable therapeutic target in the treatment of human malignancies as melanoma cells use CXCR4 for their metastatic spread [75].

In cervical cancer cell lines and primary tumor biopsies, CXCL12 is often downregulated and its promoter is hypermethylated [15]. Exogenous treatment with recombinant CXCL12 inhibited metastasis-promoting cell migration, cell invasion, and anchorageindependent cell growth events in cervical cancer cell lines (HeLa, SiHa and C-33A) [15].

The CXCL12/CXCR4 chemokine pathway is expressed in cervical cancer. The CXCL12/ CXCR4 signaling pathway plays an important role in the development of cervical cancer, the further course of this malignant disease, the development of metastases, and 
the response to radiation therapy. Preclinical studies with fractionated standard radiation therapy and simultaneous weekly administration of cisplatin plus the CXCR4 inhibitor Plerixafor (AMD3100) in xenografts from patients with orthotopic cervical cancer showed an improved response of the primary tumor and a reduced number of lymph node metastases without an increase in the early- or late-stage of side effects [76].

An in vitro study with Hela cells showed that inhibition of CXCL12 decreased cell viability and increased cellular apoptosis in radiation-treated cells [77]. After treatment with CXCL12 siRNA in the same cell culture model, the expression level of CD44 was downregulated and the expression level of CXCR4 was upregulated [77]. The regulation effect that is described above also occurred during irradiation [77]. Another in vitro study used plerixafor in combination to radio/chemotherapy and the combined treatmentinduced increases in the CXCL12/CXCR4 signaling [78]. The authors showed that this combination improves primary tumor response and reduces intestinal side effects, and that this combination warrants testing in future clinical trials [76].

In contrast to former studies, a more recent study shows that the chemokine CXCL12 and its receptor CXCR4 are constitutively overexpressed in human cancers, especially cervical cancer [79]. The interaction of CXCL12 with CXCR4 and the subsequent signal transduction plays an important role in tumor progression and metastasis. This interaction also appears to be important in the therapy-induced recruitment of CXCR4expressing cytotoxic immune cells [79]. In a recent study, Hartimath et al. investigated the feasibility of $\mathrm{N}$-[11C] methyl-AMD3465 positron emission tomography (PET) to monitor the changes in CXCR4 density in tumors after single-fraction local radiotherapy or in combination with immunization [79]. The authors demonstrated the feasibility of $N$-[11C] -methyl-AMD3465 PET imaging to monitor treatment-induced changes in the density of CXCR4 receptors in tumors. Further evaluation of CXCR4 as a potential imaging biomarker could be warranted for the development of broader anti-tumor therapies [79].

\subsection{CXCL13 and CXCL16}

Recently it was shown that hypermethylation of single CpG dinucleotides at the promoter of CXCL13 gene stimulates cell migration in cervical cancer [80]. The downregulation of CXCL13 has been linked to hypermethylation of certain genes in cervical cancer cell lines and primary tumor biopsies [80]. For example, a CpG dinucleotide on the HIF-1a transcription factor motifs in the promoter element of CXCL13 in cervical cancer cells was consistently methylated and thus associated with HIF-1a [80]. In a xenograft model with CXCL13 overexpression and S110 treatment, tumor growth and liver metastasis were suppressed, whereas its low expression increased the risk of death in cervical cancer patients [80].

A new cytokine (CXCL16) was investigated together with the chemokine receptor combination CXCL12/CXCR4 and CXCL16/CXCR6 in cervical intraepithelial neoplasia (CIN) and cervical cancer [81]. Huang et al. were able to show that an increased level of co-expression of CXCL12/CXCR4 and CXCL16/CXCR6 in CIN and cervical cancer indicates a persistent process in the development of cervical cancer. Moreover, the CXCL16/CXCR6 complex may be useful as a biomarker and a valuable prognostic factor for cervical cancer [81].

A summary of the C-X-C chemokines, its receptors and main function in cervical cancer is presented in Table 2 . The interaction between $\mathrm{C}-\mathrm{X}-\mathrm{C}$ chemokines and its receptors is displayed in Figure 2. 
Table 2. Summary of the CXC-chemokines, its distribution, and main function in cervical cancer.

\begin{tabular}{|c|c|c|c|c|}
\hline $\begin{array}{c}\text { Chemokine } \\
\text { (Alternate Names) }\end{array}$ & $\begin{array}{l}\text { Effects of the } \\
\text { Chemokine }\end{array}$ & Effects in Cervical Cancer & Receptor & References \\
\hline $\begin{array}{c}\text { CXCL1 } \\
\text { (GRO1 oncogene, } \\
\text { GRO } \alpha, \text { NAP-3, } \\
\text { MGSA- } \alpha \text { ) }\end{array}$ & $\begin{array}{l}\text { Chemoattractant for } \\
\text { immune cells, } \\
\text { endothelial tube } \\
\text { formation }\end{array}$ & $\begin{array}{l}\text { Increased cervical cancer } \\
\text { angiogenesis (AKIP1-dependent) }\end{array}$ & CXCR2 & [49] \\
\hline $\begin{array}{l}\text { CXCL2 } \\
(\mathrm{GRO} \beta)\end{array}$ & $\begin{array}{l}\text { Endothelial tube } \\
\text { formation }\end{array}$ & $\begin{array}{c}\text { Increased cervical cancer } \\
\text { angiogenesis (AKIP1-dependent) - > } \\
\text { increased } \\
\text { Cervical cancer cell proliferation }\end{array}$ & CXCR2 & [51] \\
\hline $\begin{array}{l}\text { CXCL3 } \\
(\mathrm{GRO} \gamma)\end{array}$ & $\begin{array}{l}\text { Enhanced proliferation } \\
\text { and migration activities }\end{array}$ & $\begin{array}{l}\text { Potential tumor marker and } \\
\text { interference target }\end{array}$ & CXCR2 & {$[52]$} \\
\hline $\begin{array}{l}\text { CXCL5 } \\
\text { (ENA78) }\end{array}$ & $\begin{array}{l}\text { Cell proliferation and } \\
\text { migration, regulation of } \\
\text { expression of } \\
\text { tumor-related genes }\end{array}$ & $\begin{array}{l}\text { Contributes to the tumorigenicity of } \\
\text { cervical cancer }\end{array}$ & CXCR2 & {$[53,54]$} \\
\hline $\begin{array}{l}\text { CXCL6 } \\
(\mathrm{GCP} 2)\end{array}$ & $\begin{array}{l}\text { Chemotactic for } \\
\text { neutrophil } \\
\text { granulocytes }\end{array}$ & $\begin{array}{l}\text { Inhibition via Micro-RNA-101-5p } \\
\text { leads to Inhibition of tumor growth } \\
\text { and metastasis }\end{array}$ & CXCR1, CXCR2 & {$[55,82]$} \\
\hline $\begin{array}{l}\text { CXCL8 } \\
\text { (IL-8) }\end{array}$ & $\begin{array}{l}\text { Proinflammatory, } \\
\text { endothelial tube } \\
\text { formation }\end{array}$ & $\begin{array}{c}\text { Increased cervical cancer } \\
\text { angiogenesis (AKIP1-dependent), } \\
\text { Expression is correlated with clinical } \\
\text { stage, distant metastasis, histological } \\
\text { type and grade }\end{array}$ & CXCR1, CXCR2 & {$[56,57]$} \\
\hline $\begin{array}{c}\text { CXCL10 } \\
\text { (IP-10, small-inducible } \\
\text { cytokine B10) }\end{array}$ & $\begin{array}{l}\text { Suppression of } \\
\text { angiogenesis, } \\
\text { modulating formation } \\
\text { of micro vessel and } \\
\text { expression of E6 and E7 }\end{array}$ & $\begin{array}{l}\text { Prognostic indicator for } \\
\text { cervical cancer, } \\
\text { May be used as gene therapy in } \\
\text { combination with radiotherapy }\end{array}$ & CXCR3 & {$[58,59]$} \\
\hline $\begin{array}{l}\text { CXCL11 } \\
(\mathrm{I}-\mathrm{TAC})\end{array}$ & $\begin{array}{c}\text { Chemotactic for } \\
\text { interleukin-activated } \\
\text { T-cells }\end{array}$ & $\begin{array}{l}\text { Higher expression of CXCR7 is } \\
\text { associated with shorter DFS and OS }\end{array}$ & CXCR3, CXCR7 & {$[63,82]$} \\
\hline $\begin{array}{l}\text { CXCL12 } \\
(\mathrm{SDF} 1)\end{array}$ & $\begin{array}{l}\text { Induction of directed } \\
\text { cell migration }\end{array}$ & $\begin{array}{l}\text { Chemotaxis and rescue from } \\
\text { apoptosis, linked to tumor } \\
\text { dissemination and poor prognosis }\end{array}$ & CXCR4, CXCR7 & {$[65,66,74]$} \\
\hline $\begin{array}{l}\text { CXCL13 } \\
\text { (BCA1) }\end{array}$ & Inhibits cell migration & $\begin{array}{l}\text { Low expression is associated with } \\
\text { risk of death }\end{array}$ & CXCR3, CXCR5 & {$[80]$} \\
\hline CXCL16 & $\begin{array}{l}\text { Co-expression with } \\
\text { CXCL12/CXCR4 - > } \\
\text { durative process in } \\
\text { cervical cancer } \\
\text { development }\end{array}$ & Biomarker, prognostic factor & CXCR6 & [81] \\
\hline
\end{tabular}

Abbreviations: CXCL-C-X-C motif chemokine; CXCR-C-X-C motif receptor; AKIP1-A-Kinase Interacting Protein 1; OS-overall survival; IL—interleukin; BCA1-B cell-attracting chemokine 1; SDF1—stromal cell-derived factor 1; I-TAC—Interferon-inducible T-cell alpha chemoattractant; IP—interferon-gamma induced protein; ENA78-Epithelial Neutrophil Activating Peptide 78; GRO-growth related oncogene; MGSA $\alpha$-Melanoma Growth Stimulatory Activity $\alpha$; NAP-3—Neutrophil Activating Protein 3. 


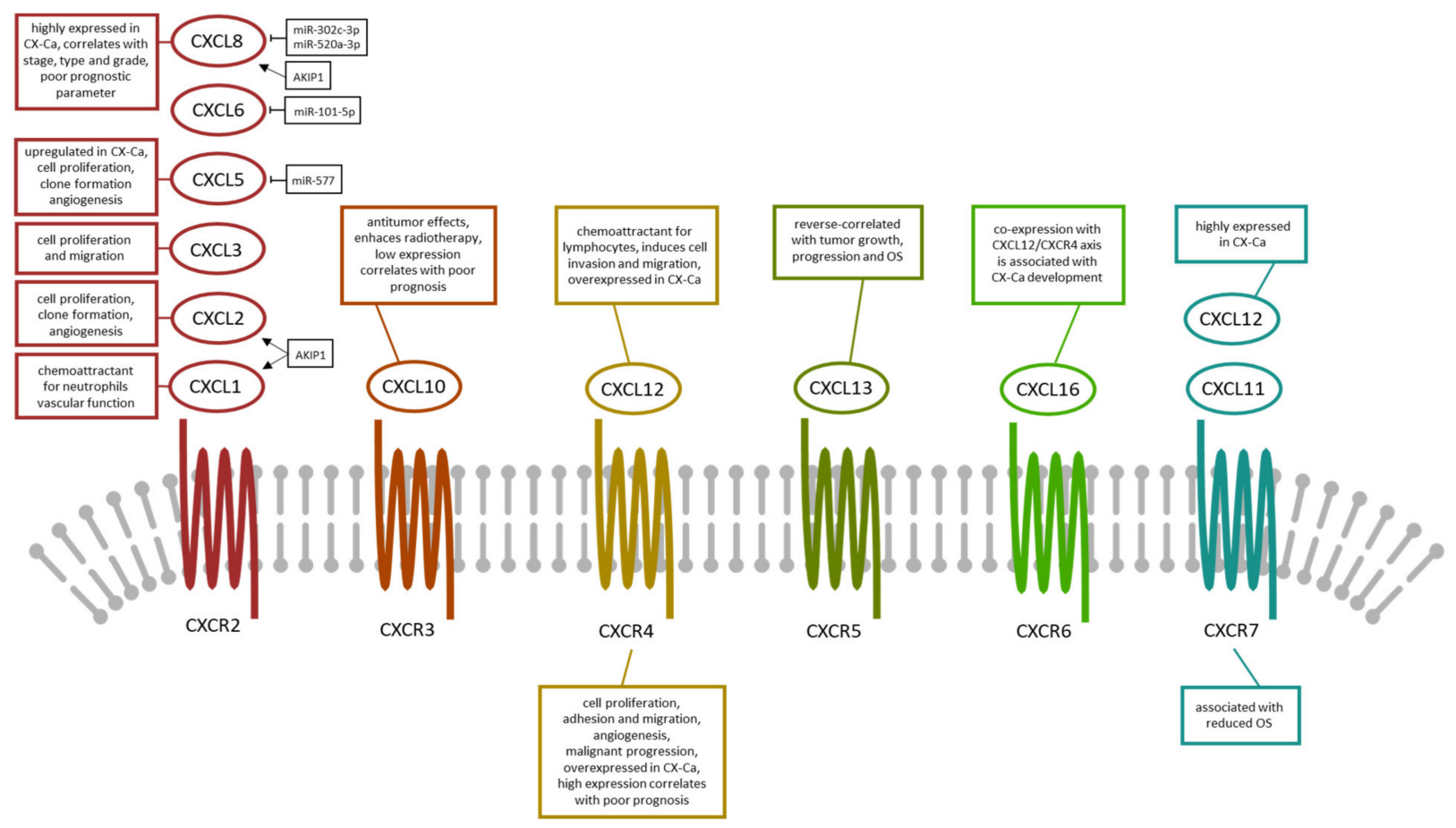

Figure 2. Summary of the CXC-chemokines, its receptor binding partner and main function in cervical cancer. A total of six CXC-chemokines (CXCL-1, -2, -3, -5, -6, $\mathcal{E}-8$ bind to the same receptor CXCR2. Abbreviations: CX-Ca-carcinoma of the uterine cervix; $\mathrm{CXCL}-\mathrm{C}-\mathrm{X}-\mathrm{C}$ motif chemokine; $\mathrm{CXCR}-\mathrm{C}-\mathrm{X}-\mathrm{C}$ motif receptor; AKIP1-A-Kinase Interacting Protein 1; OS-overall survival.

\section{The Role of Chemokines in Checkpoint Activation/Inhibition in Cervical Cancer}

Checkpoint inhibitors are among the most promising therapeutic approaches for the treatment of a variety of cancers such as cervical cancer, leading to strong immune responses against tumor cells by blocking PD1/PD-L1 or TIM-3/Gal-9.

In a recent study, Moeini et al. investigated whether the therapeutic effect of a DNA vaccine, which codes for the human papillomavirus type 16 (HPV-16) E7, through the combined application of an immune checkpoint blockade against the programmed death-1 (PD-1) signaling pathway and secondary lymphoid tissue chemokine (SLC), also known as the CCL21 adjuvant, can be enhanced in a mouse cervical carcinoma model [83]. As a result, the authors were able to show that vaccination with the described DNA vaccine in combination with the CCL21 adjuvant plus PD-1 blockade greatly increased cytotoxic T lymphocyte production and the lymphocyte proliferation rate and strongly inhibited tumor progression. The vaccine in combination with adjuvant and blockade also significantly reduced intertumoral VEGF, IL-10, and spleen IL-4, but induced the expression of spleen IFN- $\gamma$ [83].

Although the inhibition of the PD-L1/PD-1 immune checkpoints is one of the most promising approaches in immunotherapy, it is only successful in subpopulations of patients. Recent work has found recurrent copy number gains (CNG) on chromosome 9p involving PD-L1 in a number of cancers, including cervical cancer. A list of 75 genes using the TCGA dataset was recently identified. This list included genes that were severely upregulated in tumors with chromosome 9p gains including the chemokines CCL4, CCL8, CXCL10, and CXCL11 [84]. These changes were found for many cancers.

Tian et al. showed that CCR7 has the potential to be a prognosis marker for squamous cell cervical carcinoma cells and an index for tumor microenvironment change [85]. The CIBERSORT analysis showed a positive correlation between plasma cells, CD8 + T cells, and regulatory T cells and CCR7 expression within this study, suggesting that CCR7 could play a crucial role in maintaining the immunological dominance status for the tumor microenvironment [85]. 
These coherences are visualized in Figure 3.

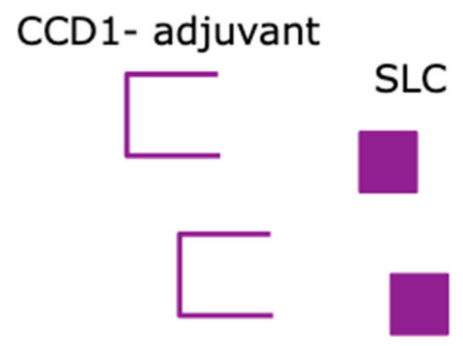

Expression of CCR7 is positive correlated with plasma cells, $\mathrm{CD} 8+\mathrm{T}$ cells and regulatory $\mathrm{T}$ cells

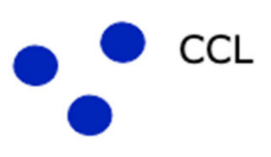

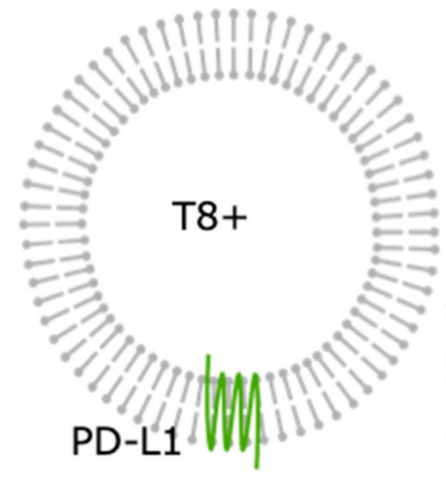

Vaccination against E7 in addition with PD-L1 blockade and CCD1adjuvant lead to rising $\mathrm{T}$ lymphocyte production and reduced tumor progression; Intratumoral VEGF, IL-10 and splenic IL-4 is reduced but splenic IFN-gamma induced
PD-L1 blockade

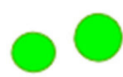

PD

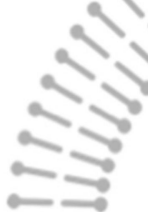

\section{(i) IIIIII: WM III Cancer \\ Upregulated genes for CCL4, \\ CCL8, CXCL10 and CXCL11}

Figure 3. Systematic depiction of the booster E7 vaccination effect by simultaneous application of PD-L1 and SLC, and correlation between plasma cells, CD8+ T cells, and regulatory T cells and the CCR7 expression. Abbreviations: CCR-C-C motif receptor; CCL-C-C motif ligand; CXCL-C-X-C motif ligand; PD-L1 - programmed cell Death protein 1 ligand; E7-HPV E7 protein; IL—interleukin; VEGF—vascular endothelial growth factor; IFN—interferon; T8+-CD8+ T cells; SLC—secondary lymphoid tissue chemokine.

\section{Conclusions}

Cervical cancer is the fourth most common cancer worldwide and the fourth leading cause of cancer death in women worldwide. About half of patients with cervical cancer have locally advanced disease for whom surgery is not an option. However, these cases would be potentially curable with the use of radiotherapy and cisplatin chemotherapy. Unfortunately, some tumors are resistant to treatment. Lymph node infiltration and recurrences are major problems in patients with advanced disease. New targeted therapies that can overcome treatment resistance and reduce metastases are urgently needed. Therefore immune-oncological research with a specific focus on chemokines and their receptors may be promising. To summarize the 27 different members of this subgroup that have been reported for mammals, referred to as CC chemokine ligands (CCL)-1 to -28, CCL-2 is the most investigated chemokine within this group of chemokines. Interestingly, macrophages/dendritic cells also seem to produce their own CCL2 in the cervical cancer environment, and, therefore, this chemokine together with others like CCL5 may be responsible for attracting tumor associated macrophages (TAM), their infiltration, and inducing their polarization toward cancer-promoting M2-phenotype [86]. The dominant member of the CXC chemokine subfamily concerning cervical cancer is CXCL12 resulting in 52 PubMed hits. Interestingly, the estrogen receptor $\alpha$ promotes cancer cell invasion via the increase of and cross-talk with infiltrated macrophages through the CCL2/CCR2/MMP9 and CXCL12/CXCR4 signaling pathways at least in lung cancer [87]. To conclude, chemokines play a direct role in cervical cancer biology. On the other hand, 
chemokines induce TAM infiltration and checkpoint activation. This is an open field of research especially considering cervical cancer.

Author Contributions: Conceptualization, F.G. and U.J.; methodology, N.D.; software, N.A.; validation, C.M.W., J.M. and F.D.; formal analysis, M.S.; investigation, M.K. and A.S.; resources, C.D.; data curation, N.D.; writing—original draft preparation, U.J.; writing—review and editing, F.G.; visualization, C.M.W.; supervision, N.D.; project administration, C.D.; funding acquisition, F.G. All authors have read and agreed to the published version of the manuscript.

Funding: This research was funded by the Medical Faculty of the University Augsburg, Doctoral Funding Program for F.G.

Institutional Review Board Statement: Not applicable.

Informed Consent Statement: Not applicable.

Data Availability Statement: All data were obtained from pubmed and they are freely available.

Acknowledgments: F.G. thanks the Medical Faculty of the University of Augsburg for support.

Conflicts of Interest: N.D. reports funding by: MSD, Novartis, Pfizer, Roche, AstraZeneca, TEVA, Mentor, and MCI Healthcare. C.D. is funded by Roche, AstraZeneca, TEVA, Mentor, and MCI Healthcare. All other authors report no conflict of interests. The funders had no role in the design of the study; in the collection, analyses, or interpretation of data; in the writing of the manuscript, or in the decision to publish the results.

\section{References}

1. Den Boon, J.A.; Pyeon, D.; Wang, S.S.; Horswill, M.; Schiffman, M.; Sherman, M.; Zuna, R.E.; Wang, Z.; Hewitt, S.M.; Pearson, R.; et al. Molecular transitions from papillomavirus infection to cervical precancer and cancer: Role of stromal estrogen receptor signaling. Proc. Natl. Acad. Sci. USA 2015, 112, E3255-E3264. [CrossRef] [PubMed]

2. Yi, M.; Li, T.; Niu, M.; Luo, S.; Chu, Q.; Wu, K. Epidemiological trends of women's cancers from 1990 to 2019 at the global, regional, and national levels: A population-based study. Biomark. Res. 2021, 9, 55. [CrossRef] [PubMed]

3. Young, R.H.; Clement, P.B. Endocervical adenocarcinoma and its variants: Their morphology and differential diagnosis. Histopathology 2002, 41, 185-207. [CrossRef] [PubMed]

4. Schiffman, M.; Wentzensen, N.; Wacholder, S.; Kinney, W.; Gage, J.C.; Castle, P.E. Human papillomavirus testing in the prevention of cervical cancer. J. Natl. Cancer Inst. 2011, 103, 368-383. [CrossRef] [PubMed]

5. Wang, Q.; Schmoeckel, E.; Kost, B.P.; Kuhn, C.; Vattai, A.; Vilsmaier, T.; Mahner, S.; Mayr, D.; Jeschke, U.; Heidegger, H.H. Higher CCL22+ Cell Infiltration is Associated with Poor Prognosis in Cervical Cancer Patients. Cancers 2019, 11, 2004. [CrossRef] [PubMed]

6. Freier, C.P.; Kuhn, C.; Endres, S.; Mayr, D.; Friese, K.; Jeschke, U.; Anz, D. FOXP3+ Cells Recruited by CCL22 into Breast Cancer Correlates with Less Tumor Nodal Infiltration. Anticancer Res. 2016, 36, 3139-3145. [PubMed]

7. Freier, C.P.; Kuhn, C.; Rapp, M.; Endres, S.; Mayr, D.; Friese, K.; Anz, D.; Jeschke, U. Expression of CCL22 and Infiltration by Regulatory T Cells are Increased in the Decidua of Human Miscarriage Placentas. Am. J. Reprod. Immunol. 2015, 74, $216-227$. [CrossRef]

8. Liu, L.B.; Xie, F.; Chang, K.K.; Shang, W.Q.; Meng, Y.H.; Yu, J.J.; Li, H.; Sun, Q.; Yuan, M.M.; Jin, L.P.; et al. Chemokine CCL17 induced by hypoxia promotes the proliferation of cervical cancer cell. Am. J. Cancer Res. 2015, 5, 3072-3084. [PubMed]

9. Ren, H.; Ren, G.; Sun, L.; Fan, X.; Wang, Y.; Li, X. Production and mechanism of CCL5 by macrophages in U14 cervical cancer-bearing mice during infection. Zhonghua Fu Chan Ke Za Zhi 2015, 50, 367-373. [PubMed]

10. Walch-Ruckheim, B.; Mavrova, R.; Henning, M.; Vicinus, B.; Kim, Y.J.; Bohle, R.M.; Juhasz-Boss, I.; Solomayer, E.F.; Smola, S. Stromal Fibroblasts Induce CCL20 through IL6/C/EBPbeta to Support the Recruitment of Th17 Cells during Cervical Cancer Progression. Cancer Res. 2015, 75, 5248-5259. [CrossRef]

11. Yu, Q.; Lou, X.M.; He, Y. Preferential recruitment of Th17 cells to cervical cancer via CCR6-CCL20 pathway. PloS ONE 2015, 10, e0120855. [CrossRef]

12. Chang, Y.W.; Chen, M.W.; Chiu, C.F.; Hong, C.C.; Cheng, C.C.; Hsiao, M.; Chen, C.A.; Wei, L.H.; Su, J.L. Arsenic trioxide inhibits CXCR4-mediated metastasis by interfering miR-520h/PP2A/NF-kappaB signaling in cervical cancer. Ann. Surg. Oncol. 2014, 21 (Suppl. 4), S687-S695. [CrossRef]

13. Kim, B.; Park, B. Baohuoside I suppresses invasion of cervical and breast cancer cells through the downregulation of CXCR4 chemokine receptor expression. Biochemistry 2014, 53, 7562-7569. [CrossRef]

14. Yadav, S.S.; Prasad, S.B.; Das, M.; Kumari, S.; Pandey, L.K.; Singh, S.; Pradhan, S.; Narayan, G. Epigenetic silencing of CXCR4 promotes loss of cell adhesion in cervical cancer. BioMed Res. Int. 2014, 2014, 581403. [CrossRef]

15. Yadav, S.S.; Prasad, S.B.; Prasad, C.B.; Pandey, L.K.; Pradhan, S.; Singh, S.; Narayan, G. CXCL12 is a key regulator in tumor microenvironment of cervical cancer: An In Vitro study. Clin. Exp. Metastasis 2016, 33, 431-439. [CrossRef] 
16. Yin, G.; Zhu, T.; Li, J.; Wu, A.; Liang, J.; Zhi, Y. CXCL12 rs266085 and TNF-alpha rs1799724 polymorphisms and susceptibility to cervical cancer in a Chinese population. Int. J. Clin. Exp. Pathol. 2015, 8, 5768-5774.

17. Zhao, M.; Ma, Q.; Xu, J.; Fu, S.; Chen, L.; Wang, B.; Wu, J.; Yang, L. Combining CXCL10 gene therapy and radiotherapy improved therapeutic efficacy in cervical cancer HeLa cell xenograft tumor models. Oncol. Lett. 2015, 10, 768-772. [CrossRef] [PubMed]

18. Dreyer, T.F.; Kuhn, S.; Stange, C.; Heithorst, N.; Schilling, D.; Jelsma, J.; Sievert, W.; Seitz, S.; Stangl, S.; Hapfelmeier, A.; et al. The Chemokine CX3CL1 Improves Trastuzumab Efficacy in HER2 Low-Expressing Cancer In Vitro and In Vivo. Cancer Immunol. Res. 2021, 9, 779-789. [CrossRef] [PubMed]

19. Gaudin, F.; Nasreddine, S.; Donnadieu, A.C.; Emilie, D.; Combadiere, C.; Prevot, S.; Machelon, V.; Balabanian, K. Identification of the chemokine CX3CL1 as a new regulator of malignant cell proliferation in epithelial ovarian cancer. PloS ONE 2011, 6, e21546. [CrossRef] [PubMed]

20. Liang, Y.; Yi, L.; Liu, P.; Jiang, L.; Wang, H.; Hu, A.; Sun, C.; Dong, J. CX3CL1 involves in breast cancer metastasizing to the spine via the Src/FAK signaling pathway. J. Cancer 2018, 9, 3603-3612. [CrossRef]

21. Liu, P.; Liang, Y.; Jiang, L.; Wang, H.; Wang, S.; Dong, J. CX3CL1/fractalkine enhances prostate cancer spinal metastasis by activating the Src/FAK pathway. Int. J. Oncol. 2018, 53, 1544-1556. [CrossRef] [PubMed]

22. Liu, W.; Liang, Y.; Chan, Q.; Jiang, L.; Dong, J. CX3CL1 promotes lung cancer cell migration and invasion via the Src/focal adhesion kinase signaling pathway. Oncol. Rep. 2019, 41, 1911-1917. [CrossRef]

23. Liu, Y.; Ma, H.; Dong, T.; Yan, Y.; Sun, L.; Wang, W. Clinical significance of expression level of CX3CL1-CX3CR1 axis in bone metastasis of lung cancer. Clin. Transl. Oncol. Off. Publ. Fed. Span. Oncol. Soc. Natl. Cancer Inst. Mex. 2021, 23, 378-388. [CrossRef]

24. Rosl, F.; Lengert, M.; Albrecht, J.; Kleine, K.; Zawatzky, R.; Schraven, B.; zur Hausen, H. Differential regulation of the JE gene encoding the monocyte chemoattractant protein (MCP-1) in cervical carcinoma cells and derived hybrids. J. Virol. 1994, 68, 2142-2150. [CrossRef] [PubMed]

25. Riethdorf, L.; Riethdorf, S.; Gutzlaff, K.; Prall, F.; Loning, T. Differential expression of the monocyte chemoattractant protein-1 gene in human papillomavirus-16-infected squamous intraepithelial lesions and squamous cell carcinomas of the cervix uteri. Am. J. Pathol. 1996, 149, 1469-1476.

26. Kleine-Lowinski, K.; Gillitzer, R.; Kuhne-Heid, R.; Rosl, F. Monocyte-chemo-attractant-protein-1 (MCP-1)-gene expression in cervical intra-epithelial neoplasias and cervical carcinomas. Int. J. Cancer 1999, 82, 6-11. [CrossRef]

27. Stiasny, A.; Kuhn, C.; Mayr, D.; Alexiou, C.; Janko, C.; Wiest, I.; Jeschke, U.; Kost, B. Immunohistochemical Evaluation of E6/E7 HPV Oncoproteins Staining in Cervical Cancer. Anticancer Res. 2016, 36, 3195-3198.

28. Stiasny, A.; Freier, C.P.; Kuhn, C.; Schulze, S.; Mayr, D.; Alexiou, C.; Janko, C.; Wiest, I.; Dannecker, C.; Jeschke, U.; et al. The involvement of E6, p53, p16, MDM2 and Gal-3 in the clinical outcome of patients with cervical cancer. Oncol. Lett. 2017, 14, 4467-4476. [CrossRef]

29. Kleine-Lowinski, K.; Rheinwald, J.G.; Fichorova, R.N.; Anderson, D.J.; Basile, J.; Munger, K.; Daly, C.M.; Rosl, F.; Rollins, B.J. Selective suppression of monocyte chemoattractant protein-1 expression by human papillomavirus E6 and E7 oncoproteins in human cervical epithelial and epidermal cells. Int. J. Cancer 2003, 107, 407-415. [CrossRef]

30. Nakamura, M.; Kyo, S.; Kanaya, T.; Yatabe, N.; Maida, Y.; Tanaka, M.; Ishida, Y.; Fujii, C.; Kondo, T.; Inoue, M.; et al. hTERTpromoter-based tumor-specific expression of MCP-1 effectively sensitizes cervical cancer cells to a low dose of cisplatin. Cancer Gene Ther. 2004, 11, 1-7. [CrossRef]

31. Zijlmans, H.J.; Fleuren, G.J.; Baelde, H.J.; Eilers, P.H.; Kenter, G.G.; Gorter, A. The absence of CCL2 expression in cervical carcinoma is associated with increased survival and loss of heterozygosity at 17q11.2. J. Pathol. 2006, 208, 507-517. [CrossRef]

32. Hou, T.; Liang, D.; Xu, L.; Huang, X.; Huang, Y.; Zhang, Y. Atypical chemokine receptors predict lymph node metastasis and prognosis in patients with cervical squamous cell cancer. Gynecol. Oncol. 2013, 130, 181-187. [CrossRef]

33. Liu, J.; Li, S.; Lin, L.; Jiang, Y.; Wan, Y.; Zhou, S.; Cheng, W. Co-expression network analysis identified atypical chemokine receptor 1 (ACKR1) association with lymph node metastasis and prognosis in cervical cancer. Cancer Biomark. Sect. A Dis. Markers 2020, 27, 213-223. [CrossRef] [PubMed]

34. Pahne-Zeppenfeld, J.; Schroer, N.; Walch-Ruckheim, B.; Oldak, M.; Gorter, A.; Hegde, S.; Smola, S. Cervical cancer cell-derived interleukin-6 impairs CCR7-dependent migration of MMP-9-expressing dendritic cells. Int. J. Cancer 2014, 134, $2061-2073$. [CrossRef] [PubMed]

35. Tao, L.; Liu, S.; Xiong, J.; Yang, H.; Wu, Y.; Xu, A.; Gong, Y. IL-1beta promotes cervical cancer through activating NF-kappaB/CCL2. Int. J. Clin. Exp. Pathol. 2021, 14, 426-433. [PubMed]

36. Coelho, A.; Matos, A.; Catarino, R.; Pinto, D.; Pereira, D.; Lopes, C.; Medeiros, R. Protective role of the polymorphism CCR2-64I in the progression from squamous intraepithelial lesions to invasive cervical carcinoma. Gynecol. Oncol. 2005, 96, 760-764. [CrossRef]

37. Coelho, A.; Matos, A.; Catarino, R.; Pinto, D.; Sousa, H.; Pereira, D.; Medeiros, R. The influence of chemokine receptor CCR2 genotypes in the route to cervical carcinogenesis. Gynecol. Obstet. Investig. 2007, 64, 208-212. [CrossRef]

38. Ivansson, E.L.; Gustavsson, I.M.; Magnusson, J.J.; Steiner, L.L.; Magnusson, P.K.; Erlich, H.A.; Gyllensten, U.B. Variants of chemokine receptor 2 and interleukin 4 receptor, but not interleukin 10 or Fas ligand, increase risk of cervical cancer. Int. J. Cancer 2007, 121, 2451-2457. [CrossRef]

39. Niwa, Y.; Akamatsu, H.; Niwa, H.; Sumi, H.; Ozaki, Y.; Abe, A. Correlation of tissue and plasma RANTES levels with disease course in patients with breast or cervical cancer. Clin. Cancer Res. Off. J. Am. Assoc. Cancer Res. 2001, 7, $285-289$. 
40. Singh, H.; Sachan, R.; Jain, M.; Mittal, B. CCR5-Delta32 polymorphism and susceptibility to cervical cancer: Association with early stage of cervical cancer. Oncol. Res. 2008, 17, 87-91. [CrossRef]

41. Chen, X.J.; Deng, Y.R.; Wang, Z.C.; Wei, W.F.; Zhou, C.F.; Zhang, Y.M.; Yan, R.M.; Liang, L.J.; Zhong, M.; Liang, L.; et al. Hypoxia-induced ZEB1 promotes cervical cancer progression via CCL8-dependent tumour-associated macrophage recruitment. Cell Death Dis. 2019, 10, 508. [CrossRef]

42. Zehbe, I.; Kaufmann, A.M.; Schmidt, M.; Hohn, H.; Maeurer, M.J. Human papillomavirus 16 E6-specific CD45RA+ CCR7+ high avidity CD8+ T cells fail to control tumor growth despite interferon-gamma production in patients with cervical cancer. $J$. Immunother. 2007, 30, 523-532. [CrossRef] [PubMed]

43. Caberg, J.H.; Hubert, P.; Herman, L.; Herfs, M.; Roncarati, P.; Boniver, J.; Delvenne, P. Increased migration of Langerhans cells in response to HPV16 E6 and E7 oncogene silencing: Role of CCL20. Cancer Immunol. Immunother. 2009, 58, 39-47. [CrossRef] [PubMed]

44. Yao, T.; Lin, Z. MiR-21 is involved in cervical squamous cell tumorigenesis and regulates CCL20. Biochim. Biophys. Acta 2012, 1822, 248-260. [CrossRef] [PubMed]

45. Zhang, J.; Zhu, D.; Lv, Q.; Yi, Y.; Li, F.; Zhang, W. The key role of astrocyte elevated gene-1 in CCR6-induced EMT in cervical cancer. Tumour Biol. J. Int. Soc. Oncodev. Biol. Med. 2015, 36, 9763-9767. [CrossRef] [PubMed]

46. Jiang, B.; Xue, M. Correlation of E6 and E7 levels in high-risk HPV16 type cervical lesions with CCL20 and Langerhans cells. Genet. Mol. Res. 2015, 14, 10473-10481. [CrossRef]

47. Yoshida, R.; Imai, T.; Hieshima, K.; Kusuda, J.; Baba, M.; Kitaura, M.; Nishimura, M.; Kakizaki, M.; Nomiyama, H.; Yoshie, O. Molecular cloning of a novel human CC chemokine EBI1-ligand chemokine that is a specific functional ligand for EBI1, CCR7. J. Biol. Chem. 1997, 272, 13803-13809. [CrossRef]

48. Yung, M.M.; Tang, H.W.; Cai, P.C.; Leung, T.H.; Ngu, S.F.; Chan, K.K.; Xu, D.; Yang, H.; Ngan, H.Y.; Chan, D.W. GRO-alpha and IL-8 enhance ovarian cancer metastatic potential via the CXCR2-mediated TAK1/NFkappaB signaling cascade. Theranostics 2018, 8, 1270-1285. [CrossRef] [PubMed]

49. Sales, K.J.; Sutherland, J.R.; Jabbour, H.N.; Katz, A.A. Seminal plasma induces angiogenic chemokine expression in cervical cancer cells and regulates vascular function. Biochim. Biophys. Acta 2012, 1823, 1789-1795. [CrossRef]

50. Gavamukulya, Y.; Maina, E.N.; El-Shemy, H.A.; Meroka, A.M.; Kangogo, G.K.; Magoma, G.; Wamunyokoli, F. Annona muricata silver nanoparticles exhibit strong anticancer activities against cervical and prostate adenocarcinomas through regulation of CASP9 and the CXCL1/CXCR2 genes axis. Tumour Biol. J. Int. Soc. Oncodev. Biol. Med. 2021, 43, 37-55. [CrossRef]

51. Zhang, W.; Wu, Q.; Wang, C.; Yang, L.; Liu, P.; Ma, C. AKIP1 promotes angiogenesis and tumor growth by upregulating CXC-chemokines in cervical cancer cells. Mol. Cell. Biochem. 2018, 448, 311-320. [CrossRef]

52. Qi, Y.L.; Li, Y.; Man, X.X.; Sui, H.Y.; Zhao, X.L.; Zhang, P.X.; Qu, X.S.; Zhang, H.; Wang, B.X.; Li, J.; et al. CXCL3 overexpression promotes the tumorigenic potential of uterine cervical cancer cells via the MAPK/ERK pathway. J. Cell Physiol. 2020, 235, 4756-4765. [CrossRef]

53. Feng, X.; Zhang, D.; Li, X.; Ma, S.; Zhang, C.; Wang, J.; Li, Y.; Liang, L.; Zhang, P.; Qu, Y.; et al. CXCL5, the upregulated chemokine in patients with uterine cervix cancer, in vivo and in vitro contributes to oncogenic potential of Hela uterine cervix cancer cells. Biomed. Pharmacother. 2018, 107, 1496-1504. [CrossRef]

54. Bai, L.; Yao, N.; Qiao, G.; Wu, L.; Ma, X. CXCL5 contributes to the tumorigenicity of cervical cancer and is post-transcriptionally regulated by miR-577. Int. J. Clin. Exp. Pathol. 2020, 13, 2984-2993.

55. Shen, W.; Xie, X.Y.; Liu, M.R.; Wang, L.L. MicroRNA-101-5p inhibits the growth and metastasis of cervical cancer cell by inhibiting CXCL6. Eur. Rev. Med Pharmacol. Sci. 2019, 23, 1957-1968. [CrossRef]

56. Yan, R.; Shuai, H.; Luo, X.; Wang, X.; Guan, B. The clinical and prognostic value of CXCL8 in cervical carcinoma patients: Immunohistochemical analysis. Biosci. Rep. 2017, 37, BSR20171021. [CrossRef]

57. Ding, H.M.; Zhang, H.; Wang, J.; Zhou, J.H.; Shen, F.R.; Ji, R.N.; Shi, J.Y.; Chen, Y.G. miR302c3p and miR520a3p suppress the proliferation of cervical carcinoma cells by targeting CXCL8. Mol. Med. Rep. 2021, 23, 322. [CrossRef]

58. Sato, E.; Fujimoto, J.; Toyoki, H.; Sakaguchi, H.; Alam, S.M.; Jahan, I.; Tamaya, T. Expression of IP-10 related to angiogenesis in uterine cervical cancers. Br. J. Cancer 2007, 96, 1735-1739. [CrossRef] [PubMed]

59. Wang, L.L.; Chen, P.; Luo, S.; Li, J.; Liu, K.; Hu, H.Z.; Wei, Y.Q. CXC-chemokine-ligand-10 gene therapy efficiently inhibits the growth of cervical carcinoma on the basis of its anti-angiogenic and antiviral activity. Biotechnol. Appl. Biochem. 2009, 53, 209-216. [CrossRef] [PubMed]

60. Yang, L.L.; Wang, B.Q.; Chen, L.L.; Luo, H.Q.; Wu, J.B. CXCL10 enhances radiotherapy effects in HeLa cells through cell cycle redistribution. Oncol. Lett. 2012, 3, 383-386. [CrossRef] [PubMed]

61. Zhang, H.; Yang, L.; Teng, X.; Liu, Z.; Liu, C.; Zhang, L.; Liu, Z. The chemokine receptor CXCR7 is a critical regulator for the tumorigenesis and development of papillary thyroid carcinoma by inducing angiogenesis In Vitro and In Vivo. Tumour Biol. J. Int. Soc. Oncodev. Biol. Med. 2016, 37, 2415-2423. [CrossRef]

62. Schrevel, M.; Karim, R.; ter Haar, N.T.; van der Burg, S.H.; Trimbos, J.B.; Fleuren, G.J.; Gorter, A.; Jordanova, E.S. CXCR7 expression is associated with disease-free and disease-specific survival in cervical cancer patients. Br. J. Cancer 2012, 106, 1520-1525. [CrossRef] [PubMed]

63. Zhao, D.; Qin, W.; Zhao, C.; Long, J.; Li, M. CXCR7, a Prognostic Biomarker in Cervical Squamous Cell Carcinoma, May Be a Screening Index for Treatment Options at Stages IB1 and IIA1. Cancer Manag. Res. 2019, 11, 10287-10296. [CrossRef] [PubMed] 
64. Xu, L.; Li, C.; Hua, F.; Liu, X. The CXCL12/CXCR7 signalling axis promotes proliferation and metastasis in cervical cancer. Med Oncol. 2021, 38, 58. [CrossRef]

65. Kodama, J.; Hasengaowa; Kusumoto, T.; Seki, N.; Matsuo, T.; Ojima, Y.; Nakamura, K.; Hongo, A.; Hiramatsu, Y. Association of CXCR4 and CCR7 chemokine receptor expression and lymph node metastasis in human cervical cancer. Ann. Oncol. Off. J. Eur. Soc. Med Oncol. 2007, 18, 70-76. [CrossRef]

66. Zhang, J.P.; Lu, W.G.; Ye, F.; Chen, H.Z.; Zhou, C.Y.; Xie, X. Study on CXCR4/SDF-1alpha axis in lymph node metastasis of cervical squamous cell carcinoma. Int. J. Gynecol. Cancer Off. J. Int. Gynecol. Cancer Soc. 2007, 17, 478-483. [CrossRef]

67. Yang, Y.C.; Lee, Z.Y.; Wu, C.C.; Chen, T.C.; Chang, C.L.; Chen, C.P. CXCR4 expression is associated with pelvic lymph node metastasis in cervical adenocarcinoma. Int. J. Gynecol. Cancer Off. J. Int. Gynecol. Cancer Soc. 2007, 17, 676-686. [CrossRef] [PubMed]

68. Walenkamp, A.M.; Boer, I.G.; Bestebroer, J.; Rozeveld, D.; Timmer-Bosscha, H.; Hemrika, W.; van Strijp, J.A.; de Haas, C.J. Staphylococcal superantigen-like 10 inhibits CXCL12-induced human tumor cell migration. Neoplasia 2009, 11, 333-344. [CrossRef] [PubMed]

69. Amine, A.; Rivera, S.; Opolon, P.; Dekkal, M.; Biard, D.S.; Bouamar, H.; Louache, F.; McKay, M.J.; Bourhis, J.; Deutsch, E.; et al. Novel anti-metastatic action of cidofovir mediated by inhibition of E6/E7, CXCR4 and Rho/ROCK signaling in HPV tumor cells. PloS ONE 2009, 4, e5018. [CrossRef]

70. Chaudary, N.; Mujcic, H.; Wouters, B.G.; Hill, R.P. Hypoxia and metastasis in an orthotopic cervix cancer xenograft model. Radiother. Oncol. J. Eur. Soc. Ther. Radiol. Oncol. 2013, 108, 506-510. [CrossRef]

71. Brule, S.; Friand, V.; Sutton, A.; Baleux, F.; Gattegno, L.; Charnaux, N. Glycosaminoglycans and syndecan-4 are involved in SDF-1/CXCL12-mediated invasion of human epitheloid carcinoma HeLa cells. Biochim. Biophys. Acta 2009, 1790, 1643-1650. [CrossRef]

72. Jaafar, F.; Righi, E.; Lindstrom, V.; Linton, C.; Nohadani, M.; Van Noorden, S.; Lloyd, T.; Poznansky, J.; Stamp, G.; Dina, R.; et al. Correlation of CXCL12 expression and FoxP3+ cell infiltration with human papillomavirus infection and clinicopathological progression of cervical cancer. Am. J. Pathol. 2009, 175, 1525-1535. [CrossRef]

73. Cai, C.; Rodepeter, F.R.; Rossmann, A.; Teymoortash, A.; Lee, J.S.; Quint, K.; Di Fazio, P.; Ocker, M.; Werner, J.A.; Mandic, R SIVmac(2)(3)(9)-Nef down-regulates cell surface expression of CXCR4 in tumor cells and inhibits proliferation, migration and angiogenesis. Anticancer Res. 2012, 32, 2759-2768. [PubMed]

74. Wen, W.W.; Xie, S.; Xin, X.L.; Geng, M.Y.; Ding, J.; Chen, Y. Oligomannurarate sulfate inhibits CXCL12/SDF-1-mediated proliferation and invasion of human tumor cells in vitro. Acta Pharmacol. Sin. 2013, 34, 1554-1559. [CrossRef] [PubMed]

75. Dillenburg-Pilla, P.; Patel, V.; Mikelis, C.M.; Zarate-Blades, C.R.; Doci, C.L.; Amornphimoltham, P.; Wang, Z.; Martin, D.; Leelahavanichkul, K.; Dorsam, R.T.; et al. SDF-1/CXCL12 induces directional cell migration and spontaneous metastasis via a CXCR4/Galphai/mTORC1 axis. FASEB J. 2015, 29, 1056-1068. [CrossRef] [PubMed]

76. Lecavalier-Barsoum, M.; Chaudary, N.; Han, K.; Koritzinsky, M.; Hill, R.; Milosevic, M. Targeting the CXCL12/CXCR4 pathway and myeloid cells to improve radiation treatment of locally advanced cervical cancer. Int. J. Cancer 2018, 143, 1017-1028. [CrossRef] [PubMed]

77. Fu, Z.; Zhang, P.; Luo, H.; Huang, H.; Wang, F. CXCL12 modulates the radiosensitivity of cervical cancer by regulating CD44. Mol. Med. Rep. 2018, 18, 5101-5108. [CrossRef] [PubMed]

78. Lecavalier-Barsoum, M.; Chaudary, N.; Han, K.; Pintilie, M.; Hill, R.P.; Milosevic, M. Correction: Targeting CXCL12/CXCR4 and myeloid cells to improve the therapeutic ratio in patient-derived cervical cancer models treated with radio-chemotherapy. $\mathrm{Br}$. $\mathrm{J}$. Cancer 2019, 121, 626. [CrossRef] [PubMed]

79. Hartimath, S.V.; Draghiciu, O.; Daemen, T.; Nijman, H.W.; van Waarde, A.; Dierckx, R.; de Vries, E.F.J. Therapy-Induced Changes in CXCR4 Expression in Tumor Xenografts Can Be Monitored Noninvasively with N-[(11)C]Methyl-AMD3465 PET. Mol. Imaging Biol. 2020, 22, 883-890. [CrossRef]

80. Ma, D.; Fan, S.B.; Hua, N.; Li, G.H.; Chang, Q.; Liu, X. Hypermethylation of Single CpG Dinucleotides at the Promoter of CXCL13 Gene Promoting Cell Migration in Cervical Cancer. Curr. Cancer Drug Targets 2020, 20, 355-363. [CrossRef]

81. Huang, Y.; Zhang, J.; Cui, Z.M.; Zhao, J.; Zheng, Y. Expression of the CXCL12/CXCR4 and CXCL16/CXCR6 axes in cervical intraepithelial neoplasia and cervical cancer. Chin. J. Cancer 2013, 32, 289-296. [CrossRef]

82. CXCL6 C-X-C Motif Chemokine Ligand 6. Available online: https://www.ncbi.nlm.nih.gov/gene/6372 (accessed on 26 July 2021).

83. Moeini, S.; Saeidi, M.; Fotouhi, F.; Mondanizadeh, M.; Shirian, S.; Mohebi, A.; Gorji, A.; Ghaemi, A. Synergistic effect of programmed cell death protein 1 blockade and secondary lymphoid tissue chemokine in the induction of anti-tumor immunity by a therapeutic cancer vaccine. Arch. Virol. 2017, 162, 333-346. [CrossRef]

84. Budczies, J.; Denkert, C.; Gyorffy, B.; Schirmacher, P.; Stenzinger, A. Chromosome 9p copy number gains involving PD-L1 are associated with a specific proliferation and immune-modulating gene expression program active across major cancer types. $B M C$ Med. Genom. 2017, 10, 74. [CrossRef]

85. Tian, W.J.; Feng, P.H.; Wang, J.; Yan, T.; Qin, Q.F.; Li, D.L.; Liang, W.T. CCR7 Has Potential to Be a Prognosis Marker for Cervical Squamous Cell Carcinoma and an Index for Tumor Microenvironment Change. Front. Mol. Biosci. 2021, 8, 583028. [CrossRef] [PubMed] 
86. Wang, Y.; Tiruthani, K.; Li, S.; Hu, M.; Zhong, G.; Tang, Y.; Roy, S.; Zhang, L.; Tan, J.; Liao, C.; et al. mRNA Delivery of a Bispecific Single-Domain Antibody to Polarize Tumor-Associated Macrophages and Synergize Immunotherapy against Liver Malignancies. Adv. Mater. 2021, 33, e2007603. [CrossRef] [PubMed]

87. He, M.; Yu, W.; Chang, C.; Miyamoto, H.; Liu, X.; Jiang, K.; Yeh, S. Estrogen receptor alpha promotes lung cancer cell invasion via increase of and cross-talk with infiltrated macrophages through the CCL2/CCR2/MMP9 and CXCL12/CXCR4 signaling pathways. Mol. Oncol. 2020, 14, 1779-1799. [CrossRef] [PubMed] 